\title{
DEAF REPUBLIC: POEMAS TRADUZIDOS
}

\section{DEAF REPUBLIC: TRANSLATED POEMS}

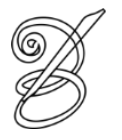

\author{
Annie Dorothea Van Der MEER ${ }^{*}$ \\ Universidade Federal do Paraná \\ Curitiba, Paraná, Brasil
}

\begin{abstract}
Resumo: Deaf Republic, de 2019, é uma obra que desafia gêneros; os poemas sobre os moradores da cidade de Vasenka e sua resistência silenciosa à repressão tecem um épico moderno, teatral e distópico. Através deste trabalho, são traduzidos pela primeira vez poemas do autor Ilya Kaminsky para o português. Buscando representar o caráter completo da narrativa, mas trazer também trechos que se sustentam por si só, foram escolhidos os poemas de abertura e fechamento, além de poemas sobre os principais personagens de Vasenka. Além disso, foram selecionados tanto os temas de horror, estupor e culpa diante da brutalidade, quanto da estranha e contínua beleza das relações humanas, um difícil balanço alcançado com maestria no trabalho de Kaminsky.

Palavras-chave: Ilya Kaminsky. Tradução de poesia. Poesia contemporânea. Tradução literária. Gêneros híbridos.

Abstract: 2019's Deaf Republic is a genre-defying work; the poems about the residents of the city of Vasenka and their silent resistance to repression weave a modern, theatrical and dystopian epic. Through this work, poems by the author Ilya Kaminsky are translated into Portuguese for the first time. To represent the thorough character of the narrative, but also bring excerpts that sustain on their one, the opening and closing poems were chosen, as well as poems about Vasenka's main characters. In addition, themes of horror, stupor and guilt in the face of brutality, as well as the strange and continuous beauty of human relations were selected, a difficult balance achieved with mastery in Kaminsky's work.
\end{abstract}

Keywords: Ilya Kaminsky. Poetry translation. Contemporary poetry. Literary translation. Cross-genre.

RECEBIDO EM: 22 de setembro de 2019

ACEITO EM: 29 de janeiro de 2020

PUBLICADO EM: março 2020 
I lya Kaminsky nasceu em 1977 em Odessa, antiga União Soviética. Surdo desde os quatro anos de idade, desde 1993 vive nos Estados Unidos, onde conseguiu asilo político com sua família. É tradutor, editor e professor na Universidade de San Diego, onde vive, e cofundador do coletivo Poets for Peace. Sua primeira coletânea de poemas em inglês, Dancing in Odessa, foi publicada em 2004, e seus livros já foram traduzidos em mais de 20 línguas. Kaminsky tem sido reconhecido por crítica e público; é um dos ganhadores da Bolsa Guggenheim, e em 2019, com a publicação de Deaf Republic, foi finalista do National Book Award, além de ser incluído nas listas de melhores livros do ano do New York Times, Washington Post, Times Literary Supplement, The Telegraph, Publishers Weekly, The Guardian, Lithub, entre outros. Também foi selecionado pela BBC como "um dos 12 artistas que mudaram o mundo em 2019."

Os poemas aqui selecionados fazem parte do livro Deaf Republic, de 2019, um épico moderno que mistura fábula, poesia e drama, tecendo a vida em uma cidade fictícia na qual os cidadãos, diante de intensa repressão militar, se tornam surdos como forma de resistência, desenvolvendo secretamente uma língua de sinais contra as autoridades. Sendo uma obra muito particular, foram escolhidos poemas que, embora façam parte de uma narrativa maior, também funcionam separadamente. Estão presentes os poemas que abrem e fecham o livro (respectivamente o primeiro e último poema desta seleção), além de um poema sobre cada um dos personagens principais. A seleção também buscou reunir tanto os temas de horror e violência da obra, quanto sua valente insistência na permanência da humanidade.

\section{Vivemos felizes durante a Guerra}

E quando jogaram bombas nas casas dos outros, nós

protestamos

mas não o bastante, nos opomos mas não

o bastante. Eu estava

em minha cama, ao redor da cama a América

caía: casa invisível por casa invisível por casa invisível.

Puxei uma cadeira pra fora e assisti o sol.

\section{We Lived Happily During the War}

And when they bombed other people's houses, we

protested

but not enough, we opposed them but not

enough. I was

in my bed, around my bed America

was falling: invisible house by invisible house by invisible house.

I took a chair outside and watched the

sun. 
No sexto mês,

do desastroso reinado na casa do dinheiro

na rua do dinheiro na cidade do dinheiro no país do dinheiro,

nosso grande país do dinheiro, nós (nos perdoe)

vivemos felizes durante a guerra.

\section{Elogio}

Você tem que falar não só da grande devastação-

ouvimos isso não de um filósofo mas de nosso vizinho, Alfonso-

de olhos fechados, ele escalou as varandas dos outros e declamou à sua filha nosso Hino Nacional:

Você tem que falar não só da grande devastaçãoquando sua filha chorou, ele

lhe fez um chapéu de jornal e espremeu seu silêncio

como duas pregas de um acordeão:

Nós temos que falar não só da grande devastação-

e ele tocou aquele acordeão desafinado em um país

onde o único instrumento musical é a porta.

\section{Enquanto a criança dorme, Sonya se despe}

Ela me esfrega até que cuspo

água ensaboada

"Porco", ela sorri-
In the sixth month

of a disastrous reign in the house of

money

in the street of money in the city of money in the country of money, our great country of money, we (forgive us)

lived happily during the war.

\section{Eulogy}

You must speak not only of great devastation-

we heard that not from a philosopher but from our neighbor, Alfonso-

his eyes closed, he climbed other people's porches and recited to his child our National Anthem:

You must speak not only of great devastation-

when his child cried, he

made her a newspaper hat and squeezed his silence

like two pleats of an accordion:

We must speak not only of great devastationand he played that accordion out of tune in a country

where the only musical instrument is the door.

\section{While the child sleeps, Sonya undresses}

She scrubs me until I spit

soapy water.

"Pig," she smiles- 
"Um homem deve cheirar melhor que seu país-"

tal é o silêncio

de uma mulher que fala contra o silêncio, sabendo

silêncio é o que nos move a falar-

Ela lança meus sapatos

E óculos no ar,

"Eu sou de povo surdo

e não tenho

país além de uma banheira e um bebê e uma cama de casal!"

Ensaboar juntos - isso

é sagrado para nós.

Lavar os ombros um do outro.

Você pode foder

360 qualquer um - mas com quem pode sentar

na água?

\section{Brinde de Galya}

À sua voz, uma misteriosa virtude, aos vinte e seis ossos de um pé, as quatro dimensões de respirar

ao pinheiro, sequoia, samambaia, menta, ao jacinto e lírios azuis,

ao jumento do maquinista em uma corda, ao cheiro de limões, um menino mijando esplendidamente contra as árvores.

Abençoe cada coisa na terra até que adoeça, até que cada coração insubmisso admita: Eu me confundi

contudo amei-e o que amei

esqueci, e o que esqueci trouxe glória a minhas viagens,
"A man should smell better than his country-"

such is the silence

of a woman who speaks against silence, knowing

silence is what moves us to speakShe throws my shoes and glasses in the air,

"I am of deaf people and I have no country but a bathtub \& an infant $\&$ a marriage bed!"

Soaping together-that is sacred to us.

Washing each other's shoulders.

You can fuck anyone- but with whom can you sit in water?

\section{Galya's toast}

To your voice, a mysterious virtue, to the twenty-six bones of one foot, the four dimensions of breathing,

to pine, redwood, sword fern, peppermint, to hyacinth and bluebell lily,

to the train conductor's donkey on a rope, to the smell of lemons, a boy pissing splendidly against the trees.

Bless each thing on earth until it sickens, until each ungovernable heart admits: $I$ confused myself

and yet I loved - and what I loved I forgot, what I forgot brought glory to my travels, 
to you I travelled as close as I dared, Lord.

\section{Em um tempo de paz}

Habitante da terra há quarenta e poucos anos

Uma vez me encontrei em um país em paz. Assisto vizinhos abrirem

seus celulares para assistir um policial exigindo a carteira de motorista de um homem. Quando um homem pega sua carteira, o policial atira. Dentro da janela do carro. Atira.

É um país em paz.

Embolsamos nossos celulares e vamos. Ao dentista, buscar as crianças na escola, comprar xampu e manjericão.

Nosso é um país onde um menino baleado pela polícia jaz na calçada por horas.

Vemos em sua boca aberta a nudez de toda a nação.

Nós assistimos. Assistimos outros assistirem.

O corpo do menino jaz na calçada exatamente como o corpo de um menino-

É um país em paz.

E que apara os corpos de seus cidadãos sem esforço, da forma que a mulher do Presidente apara suas unhas dos pés.

\section{In a time of peace}

Inhabitant of earth for fortysomething years

I once found myself in a peaceful country. I watch neighbors open

their phones to watch

a cop demanding a man's driver's license. When a man reaches for his wallet, the cop

shoots. Into the car window. Shoots.

It is a peaceful country.

We pocket our phones and go.

To the dentist, to pick up the kids from school, to buy shampoo and basil.

Ours is a country in which a boy shot by police lies on the pavement for hours.

We see in his open mouth the nakedness of the whole nation.

We watch. Watch others watch.

The body of a boy lies on the pavement exactly like the body of a boy-

It is a peaceful country.

And it clips our citizens' bodies effortlessly, the way the President's wife trims her toenails.

Todos nós

All of us 
ainda temos o trabalho duro das consultas ao dentista,

de lembrar de fazer

uma salada de verão: manjericão, tomates, é uma alegria, tomates, ponha um pouco de sal.

Este é um tempo de paz.

Eu não ouço tiros, mas assisto pássaros espirrarem nos quintais dos subúrbios. Como brilha o céu enquanto a avenida gira em seus eixos. Como brilha o céu (me perdoe) como brilha. still have to do the hard work of dentist appointments, of remembering to make a summer salad: basil, tomatoes, it is a joy, tomatoes, add a little salt.

This is a time of peace.

I do not hear gunshots, but watch birds splash over the back yards of the suburbs. How bright is the sky as the avenue spins on its axis. How bright is the sky (forgive me) how bright.

\section{REFERÊNCIAS}

362 ILYA KAMINSKY. About. Disponível em: https://www.ilyakaminsky.com/about Acesso em: 15 set. 2019.

KAMINSKY, Ilya. Deaf Republic. New York: Graywolf Press, 2019.

YOUNG, Kevin. From "Deaf Republic" The New Yorker, New York, 11 fev. 2019.

Disponível em: https://www.newyorker.com/magazine/2019/02/18/deaf-republic Acesso em: 30 jul. 2019.

\footnotetext{
i* Annie Dorothea van der MEER - Graduanda em Letras Português e Inglês na Universidade Federal do Paraná. Universidade Federal do Paraná, Setor de Ciências Humanas. Curitiba, Paraná, Brasil.

Currículo acadêmico: http://lattes.cnpq.br/5641966722723862

ORCID: https://orcid.org/0000-0003-2656-5520

E-mail: annie42m@gmail.com
} 